\title{
An evaluation of national patents and utility models during the last decade in the field of orthopedics and traumatology in Turkey
}

\section{Türkilye"de son on yıl içinde ortopedi ve travmatoloji alanında ulusal patent ve faydalı modellerin} değerlendirilmesi

Yaşar Mahsut Dincel ${ }^{1}$,Yunus Emre Akman²,Ahmet Uğur Güir ${ }^{3}$, Teyfik Demirr ${ }^{3}$,Ibrahim Azboy ${ }^{4}$

'Namık Kemal University, Faculty of Medicine, Department of Orthopedics and Traumatology Tekirdağ, Turkey

${ }^{2}$ İstanbul Bilim Unıversty, Faculty of Medicine, Department of Orthopedics and Traumatology İstanbul, Turkey

${ }^{3}$ TOBB Economics, and Technology University Mechanical Engineering Department.Ankara, Turkey.

${ }^{4}$ Istanbul Medipol University,Faculty of Orthopedics and Traumatology. Istanbul, Turkey

Corresponding author: Yaşar Mahsut Dincel, MD, Namık Kemal University, Faculty of Medicine, Department of Orthopedics and Traumatology Tekirdağ, Turkey

E-mail: ymd61@hotmail.com

Received/Accepted: May 20, 2019 /September 28, 2019

Conflict of interest: There is not a conflict of interest.

\section{SUMMARY}

Objective: The aim of this study was to evaluate the number and status of national patents and utility models, which had been applied for, registered or has become invalid in the field of orthopedics and traumatology in Turkey between 2007 and 2017. In addition, we aimed to categorize these patents and identify the areas with the most inventions.

Method: A61B17, A61F2, and A61F5 patent categories, which were relevant to orthopedics and traumatology and were applied for between 2007 and 2017 were investigated. In total, 341 patents and utility models which had a registration number, were pending for approval and those who lost validity were included in the study and categorized according to their subjects.

Results: Of the 341 patents and utility models, 172 were registered and valid, 73 were pending for approval, and 96 were invalid due to unpaid fees. The leading fields in categorical classification were spinal surgery with 121 patents and trauma surgery with 102 patents. According to subcategorical classification, implants led the group with 207 patents, followed by auxiliary tools with 62 patents. About $1 / 3$ of the registered patents had lost validity.

Conclusions: To the best of our knowledge, this is the first study that investigates the status of the patents in the field of orthopedic and traumatology in Turkey. Spinal and trauma-related patents were the leading categories. One-third of the patent applications were invalid due to unpaid fees. Our study can be used as a reference in future studies investigating the patents and utility models.

Keywords: Orthopedics; patent; traumatology; utility model; Turkey

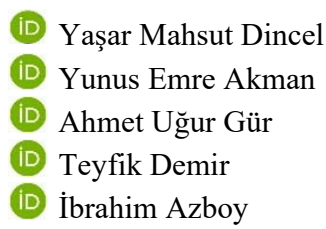

ORCID IDs of the authors: Y.M.D. 0000-0001-6576-1802

Y.E.A. 0000-0003-2939-0519

A.U.G. 0000-0001-8590-1083

T.D. $0000-0001-6352-8302$

İ.A. 0000-0003-0926-3029 
Amaç: Bu çalıșmanın amacı 2007 ve 2017 yılları arasında Türkiye'de ortopedi ve travmatoloji alanında başvurulan, kayıt altına alınmış veya geçersiz hale gelen ulusal patent ve faydalı modellerin sayısını ve durumunu değerlendirmektir. Ayrıca, bu patentleri kategorize etmeyi ve bu alanlarda en fazla yapılan icatları tanımlamayı hedefledik.

Yöntem: Ortopedi ve travmatoloji ile ilgili olan A61B17, A61F2 ve A61F5 patent kategorileri, 2007 ve 2017 y1llar1 arasında incelenmiştir. Toplamda, kayıt numarası olan 341 patent ve faydalı model onay için beklemede ve geçerliliğini yitirmiş olanlar dahil edilmiştir. Çalışma ve konularına göre kategorize edildi. Kayıtlı ve geçerli toplam 168 patent ve faydalı model vardı. Bunlardan 76'sı onay için beklemede idi ve ödenmemiş yıllık patent ücretleri nedeniyle 97'si geçersizdi. Kategorik sinıflamanın önde gelen alanları, 121 patent ve 102 patentli travma cerrahisi ile spinal cerrahi idi. Alt kategorik sınıflandırmaya göre, implantlar 207 patentli gruba liderlik etti, ardından 62 patentli yardımcı araçlar izledi. Kayıtlı patentlerin yaklaşık 1 / 3'ü geçerliliğini yitirmişti.

Sonuç: Bildiğimiz kadarıyla, bu çalışma Türkiye'de ortopedi ve travmatoloji alanındaki patentlerin durumunu araştıran ilk çalışmadır. Spinal ve travma ile ilgili patentler ilk sıradadır. Ödenmemiş yıllık patent ücretleri nedeniyle patent başvurusunun üçte biri geçersizdir. Çalışmamız, ortopedi ve travmatoloji ya da diğer alanlardaki patent ve faydalı modelleri araştıran gelecekteki çalışmalarda referans olarak kullanılabilir.

Anahtar sözcükler: Ortopedi ,travmatoloji,patent,faydalı model,Türkiye

\section{INTRODUCTION}

Copyright protection of patents has started with the Venetian Patent Statute enacted in $1474^{1,2}$. The statute which intends to encourage invention for the public good and protect the honor of invention offered protection for 10 years ${ }^{1,3}$. The second legislation regarding this topic was the Statute of Monopolies of 1623 which was an Act of the Parliament of England notable as the first statutory expression of English patent law. Other legislations for patent protection that followed were in 1790 in the US, in 1791 in France, in 1877 in Germany and in 1879 in Turkey.

A historical review of the legislation on patents show that the Turkish Patent Law is among the first recognized legislations ${ }^{4,5}$. The Turkish Patent and Trademark Office (TPTO; formerly known as the Turkish Patent Institute) was founded to share the knowledge and materials related to patents and trademarks with the public in an attempt to realize technological advancement, create a competitive environment and foster the research-development facilities. ${ }^{6}$ Patents prevent the unauthorized reproduction, use or sales of an invention by a third party for a limited time period in a specific country. The document for the 'use of copyrights' is called 6,7 the Patent Certificate (PC).

Utility model (UM) is a relatively new intellectual property right intended to protect the inventions applicable in the industry ${ }^{6,8}$. The UM certificate can be obtained in a shorter time and with less cost than the PC. UM license does not require the 'inventive step' criterion. The inventive step is a general patentability requirement present in most patent laws, according to which an invention should be sufficiently inventive -i.e., not apparent to the skilled person in the light of state of the artin order to be patented. Since it does not contain an inventive step, the products and methods fit for a UM certificate are not granted protection. These products and methods must not have been declared in written or oral form, or used before in public. Industrial applicability means that the product or the way possesses more practical features rather than being entirely theoretical. The simplified application process of $\mathrm{UM}$ and the lack of investigation and evaluation phases work in favor of the ${ }^{6,9,10}$ applicant.The differences between patents and UMs are summarized in Table 1.

The literature does not contain any data about the number of patents and UMs in the field of orthopedics and traumatology or other areas of medicine. In this study, we aimed to evaluate the number and status of the national patents and UMs, which had been applied for, registered or has become invalid in the field of orthopedics and traumatology between 2007 and 2017 in Turkey. In addition, we aimed to categorize these patents and identify the areas with the most inventions. 
Table 1: Key features of patents and utility models.

\begin{tabular}{|l|c|c|}
\hline & Patents & Utility Models \\
\hline Novelty & + & + \\
\hline Invention step & + & - \\
\hline Industrial applicability/usefulness & + & + \\
\hline Methods and products of these methods & + & - \\
\hline Chemical substances & + & - \\
\hline Research & + & - \\
\hline Review & + & - \\
\hline Publication & + & + \\
\hline Copyright protection & $20 / 7$ years & 10 years \\
\hline
\end{tabular}

\section{MATERIAL AND METHODS}

Using a patent tracking software (Marksoft v.13.7.4.0; Marksoft Yazılım, Ankara, Turkey) and the database of the TPTO, patents and UMs from the A61B17, A61F2 and A61F5 patent categories (those that fall under the 'Medical Instruments and Supplies' heading listed in Section 3, Class 32.50 of the Statistical Classification of Economic Activities 4,5 in the European Community [NACE codes Rev. 2]), which included the most relevant patents and UMs for the field of orthopedics and traumatology and applied for between 2007 and 2017, were investigated.

The A61B17 category covers surgical instruments, devices, and methods. The A61F2 category includes: filters implantable into blood vessels; prostheses, in other words, artificial substitutes or replacements for various body parts; apparatus, devices or methods for physically correcting or altering the body of patients or disabled persons; and devices providing patency to, or preventing collapsing of, tubular structures of the body. The A61F5 category covers the orthopedic methods and tools for non-surgical treatment of the bones and joints.

The 585 patents and UMs retrieved were reviewed, and the 244 left outside the interest of orthopedics and traumatology were excluded. The remaining 341 which had a registration number, were pending for approval, and those who lost validity were included in the study. The patents and UMs were categorized according to their subjects and the material used in their production (Table 2).

Table 2. An overview of the patents and utility models and their classification based on categories and subcategories.

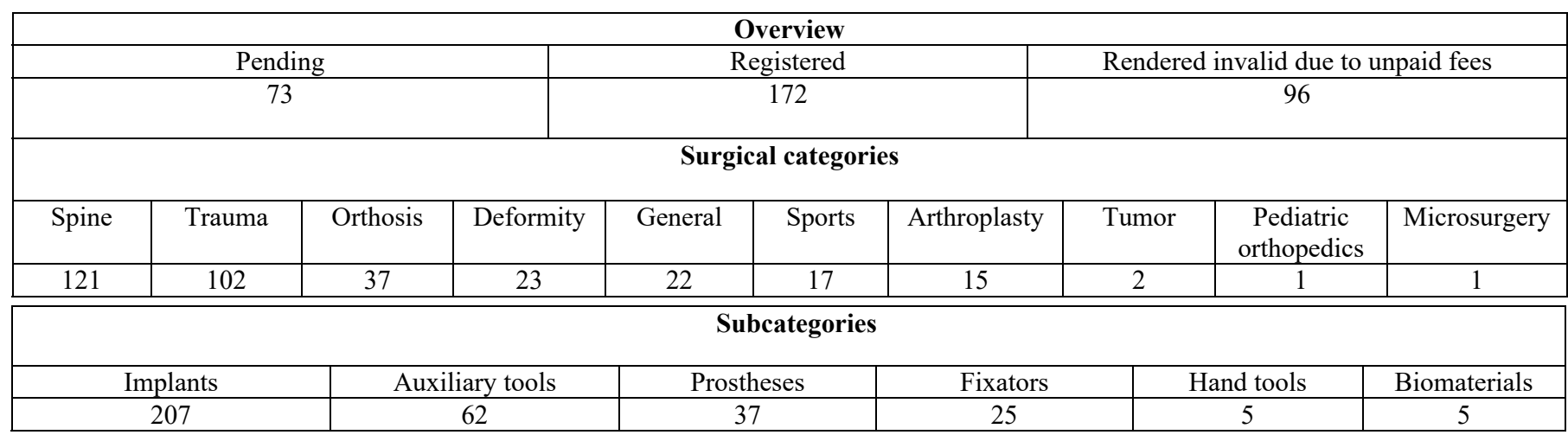

\section{Statistical method}

Frequency and percentage values were used in descriptive statistics to evaluate the patents and UMs based on the years and their categories.
Statistical analyses were performed using the SPSS v.22 (SPSS Inc., Chicago, IL, USA) software. 


\section{RESULTS}

The A61B17 category held 204 patents and UMs. Thirty-six of them were pending for approval, 103 were registered, and 65 were rendered invalid due to unpaid fees. The field of trauma had the most patent and UMs $(\mathrm{n}=86,42.2 \%)$, whereas microsurgery patents claimed the last place $(n=1$,
$0.5 \%$ ). The fields of orthoses, tumor surgery, and pediatric orthopedics had no registries (Table 3, Fig. 1). A review of the subcategories revealed that the implants had the highest number of patents and UMs $(n=132,64.7 \%)$, whereas the biomaterials had the fewest $(n=2,1.0 \%)$. The prostheses category had no registries (Table 4, Fig. 2).

Table 3: Number and percentage of the patents in the A61F2, A61B17, and A61F5 categories.

\begin{tabular}{|c|c|c|c|c|c|c|c|c|}
\hline \multirow[b]{2}{*}{ Surgical Category } & \multicolumn{2}{|c|}{ Total } & \multicolumn{2}{|c|}{ A61B17 } & \multicolumn{2}{|c|}{ A61F2 } & \multicolumn{2}{|c|}{ A61F5 } \\
\hline & $\mathrm{n}$ & $\%$ & $\mathrm{n}$ & $\%$ & $\mathrm{n}$ & $\%$ & $\mathrm{n}$ & $\%$ \\
\hline Spine & 121 & $35.5 \%$ & 70 & $57.9 \%$ & 49 & $40.5 \%$ & 2 & $7.1 \%$ \\
\hline Trauma & 102 & $29.9 \%$ & 86 & $84.3 \%$ & 9 & $8.8 \%$ & 7 & $25.0 \%$ \\
\hline Orthosis & 37 & $10.9 \%$ & 0 & $0.0 \%$ & 24 & $64.9 \%$ & 13 & $46.4 \%$ \\
\hline Deformity & 23 & $6.7 \%$ & 13 & $56.5 \%$ & 5 & $21.7 \%$ & 5 & $17.9 \%$ \\
\hline General & 22 & $6.5 \%$ & 18 & $81.8 \%$ & 4 & $18.2 \%$ & 0 & $0.0 \%$ \\
\hline Sports & 17 & $5.0 \%$ & 13 & $76.5 \%$ & 4 & $23.5 \%$ & 0 & $0.0 \%$ \\
\hline Arthroplasty & 15 & $4.4 \%$ & 3 & $20.0 \%$ & 12 & $80.0 \%$ & 0 & $0.0 \%$ \\
\hline Tumor & 2 & $0.6 \%$ & 0 & $0.0 \%$ & 2 & $100.0 \%$ & 0 & $0.0 \%$ \\
\hline Pediatric orthopedics & 1 & $0.3 \%$ & 0 & $0.0 \%$ & 0 & $0.0 \%$ & 1 & $3.6 \%$ \\
\hline Microsurgery & 1 & $0.3 \%$ & 1 & $100.0 \%$ & 0 & $0.0 \%$ & 0 & $0.0 \%$ \\
\hline
\end{tabular}

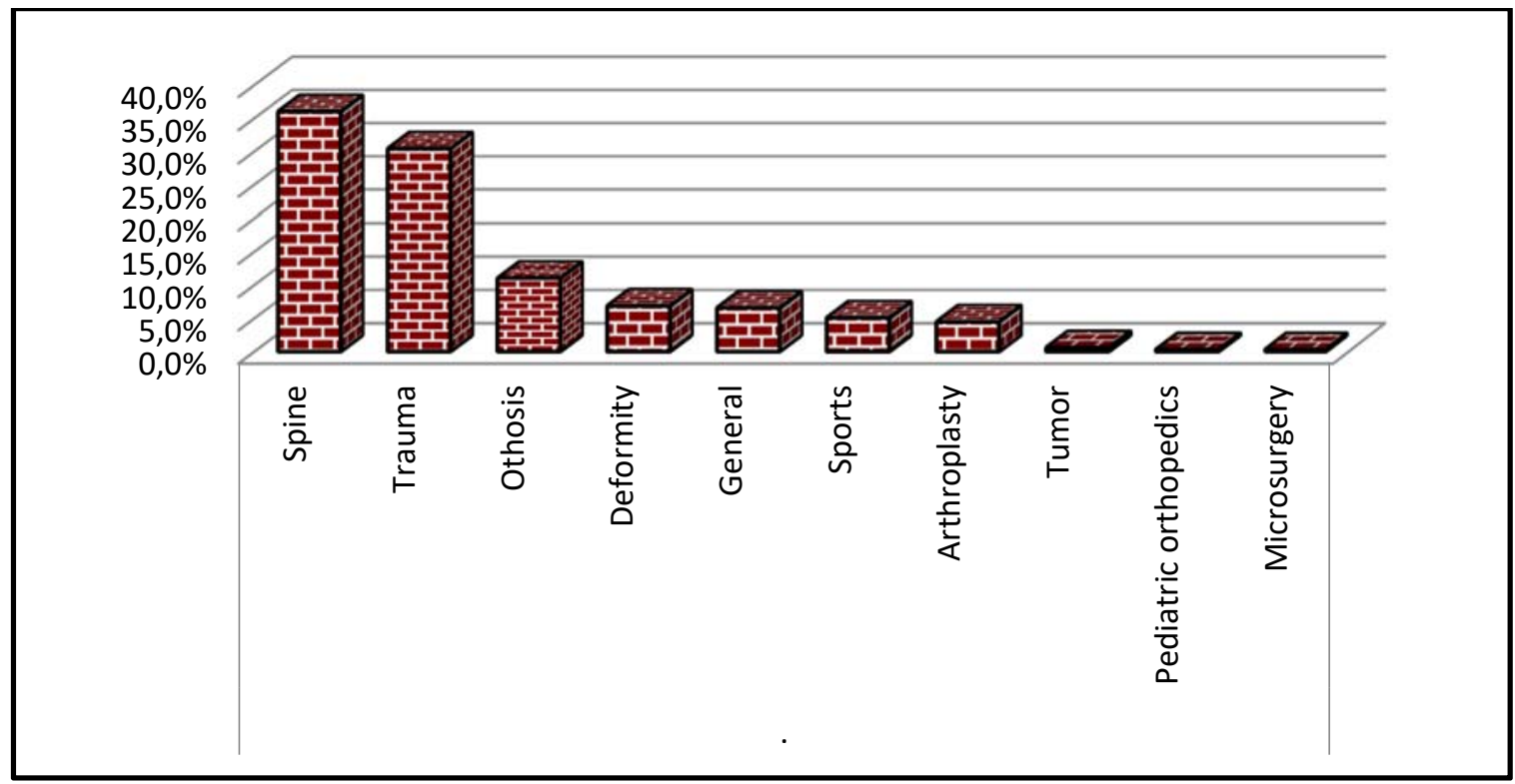

Figure 1: The highest number of patent applications was associated with spinal surgery, followed by trauma surgery.

The A61F2 category held 109 patents and UMs. Twenty-nine of them were pending for approval, 57 were registered, and 23 were rendered invalid due to unpaid fees. The field of spinal surgery had the most patents and UMs ( $\mathrm{n}=49,45.0 \%)$. The area of tumor surgery took the last place $(\mathrm{n}=2,1.8 \%)$. The areas of pediatric orthopedics and microsurgery had no registries (Table 3, Fig. 1). A review of the subcategories revealed that the implants had the highest number of patents and UMs $(n=66,60.6 \%)$, whereas the fixators had the fewest $(n=2,1.8 \%)$. Hand tools had no patent or UM registries (Table 4, Fig. 2). 
Table 4: The number and percentage of the patents and utiliy models in subcategories.

\begin{tabular}{|c|c|c|c|c|c|c|c|c|}
\hline \multirow[b]{2}{*}{ Material } & \multicolumn{2}{|c|}{ Total } & \multicolumn{2}{|c|}{ A61B17 } & \multicolumn{2}{|c|}{ A61F2 } & \multicolumn{2}{|c|}{ A61F5 } \\
\hline & $\mathrm{n}$ & $\%$ & $\mathrm{n}$ & $\%$ & $\mathrm{n}$ & $\%$ & $\mathrm{n}$ & $\%$ \\
\hline Implants & 207 & $60.7 \%$ & 132 & $64.7 \%$ & 66 & $60.6 \%$ & 9 & $32.1 \%$ \\
\hline Auxiliary tools & 62 & $18.2 \%$ & 45 & $22.1 \%$ & 14 & $12.8 \%$ & 3 & $10.7 \%$ \\
\hline Prostheses & 37 & $10.9 \%$ & 0 & $0.0 \%$ & 24 & $22.0 \%$ & 13 & $46.4 \%$ \\
\hline Fixators & 25 & $7.3 \%$ & 20 & $9.8 \%$ & 2 & $1.8 \%$ & 3 & $10.7 \%$ \\
\hline Hand tools & 5 & $1.5 \%$ & 5 & $2.5 \%$ & 0 & $0.0 \%$ & 0 & $0.0 \%$ \\
\hline Biomaterials & 5 & $1.5 \%$ & 2 & $1.0 \%$ & 3 & $2.8 \%$ & 0 & $0.0 \%$ \\
\hline
\end{tabular}

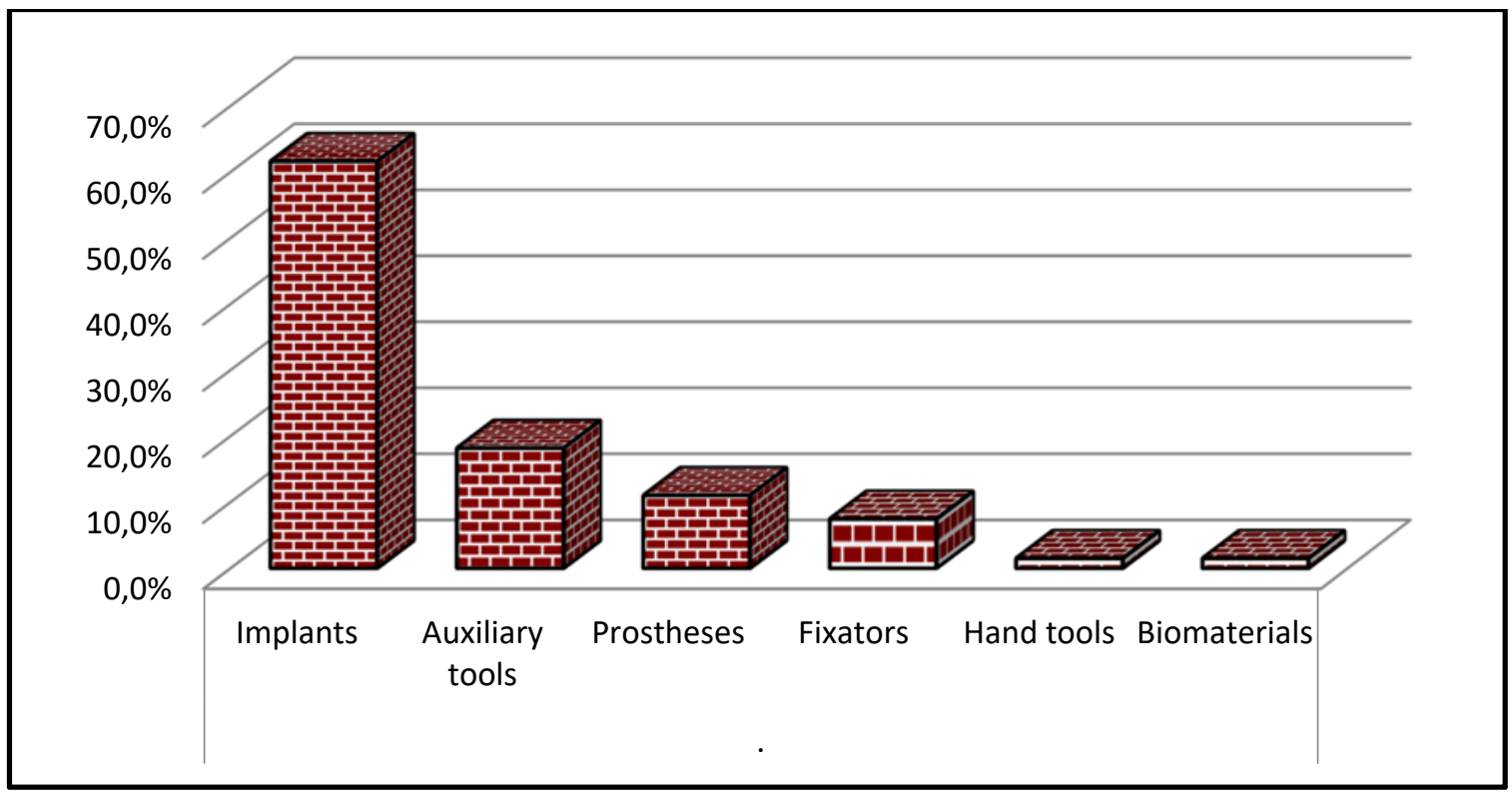

Figure 2: Among the subcategories, the highest number of patent applications was for implants, followed by auxiliary tools.

The A61F5 category held a total of 28 patents and UMs. Eight of them were pending for approval, 12 were registered, and 8 were rendered invalid. A categorical review showed that most patents and UMs $(n=13,46.4 \%)$ were related to trauma, whereas pediatric orthopedics patents and UMs had the least number of registries $(n=1,3.6 \%)$. No records were found regarding general surgery, sports surgery, arthroplasty, tumor surgery and microsurgery (Table 3, Fig. 1). In subcategorical review, the prostheses had the highest number of patents, and UMs ( $\mathrm{n}=13,46.4 \%)$ and the auxiliary tools and the fixators had the lowest $(n=3,10.7 \%)$. Hand tools and biomaterials had no registries (Table 4, Fig. 2).

The year 2012 saw the highest number of patents and UMs (23.5\%), followed by 2014 (16.1\%) and $2015(11.7 \%)$. The fewest number of patents and UMs (5.6\%) were observed in 2008 (Table 5, Fig. $3)$. 
Table 5. Distribution of patent and utility model applications based on the categories by years.

\begin{tabular}{|c|c|c|c|c|c|c|c|c|}
\hline \multirow[b]{2}{*}{ Year } & \multicolumn{2}{|c|}{ Total } & \multicolumn{2}{|c|}{ A61B17 } & \multicolumn{2}{|c|}{ A61F2 } & \multicolumn{2}{|c|}{ A61F5 } \\
\hline & $\mathrm{n}$ & $\%$ & $\mathrm{n}$ & $\%$ & $\mathrm{n}$ & $\%$ & $\mathrm{n}$ & $\%$ \\
\hline 2016 & 20 & $5.9 \%$ & 12 & $5.9 \%$ & 6 & $5.5 \%$ & 2 & $7.1 \%$ \\
\hline 2015 & 40 & $11.7 \%$ & 16 & $7.8 \%$ & 19 & $17.4 \%$ & 5 & $17.9 \%$ \\
\hline 2014 & 55 & $16.1 \%$ & 37 & $18.1 \%$ & 15 & $13.8 \%$ & 3 & $10.7 \%$ \\
\hline 2013 & 35 & $10.3 \%$ & 15 & $7.4 \%$ & 16 & $14.7 \%$ & 4 & $14.3 \%$ \\
\hline 2012 & 80 & $23.5 \%$ & 56 & $27.5 \%$ & 18 & $16.5 \%$ & 6 & $21.4 \%$ \\
\hline 2011 & 24 & $7.0 \%$ & 14 & $6.9 \%$ & 9 & $8.3 \%$ & 1 & $3.6 \%$ \\
\hline 2010 & 27 & $7.9 \%$ & 16 & $7.8 \%$ & 8 & $7.3 \%$ & 3 & $10.7 \%$ \\
\hline 2009 & 21 & $6.2 \%$ & 15 & $7.4 \%$ & 5 & $4.6 \%$ & 1 & $3.6 \%$ \\
\hline 2008 & 19 & $5.6 \%$ & 11 & $5.4 \%$ & 6 & $5.5 \%$ & 2 & $7.1 \%$ \\
\hline 2007 & 20 & $5.9 \%$ & 12 & $5.9 \%$ & 7 & $6.4 \%$ & 1 & $3.6 \%$ \\
\hline
\end{tabular}

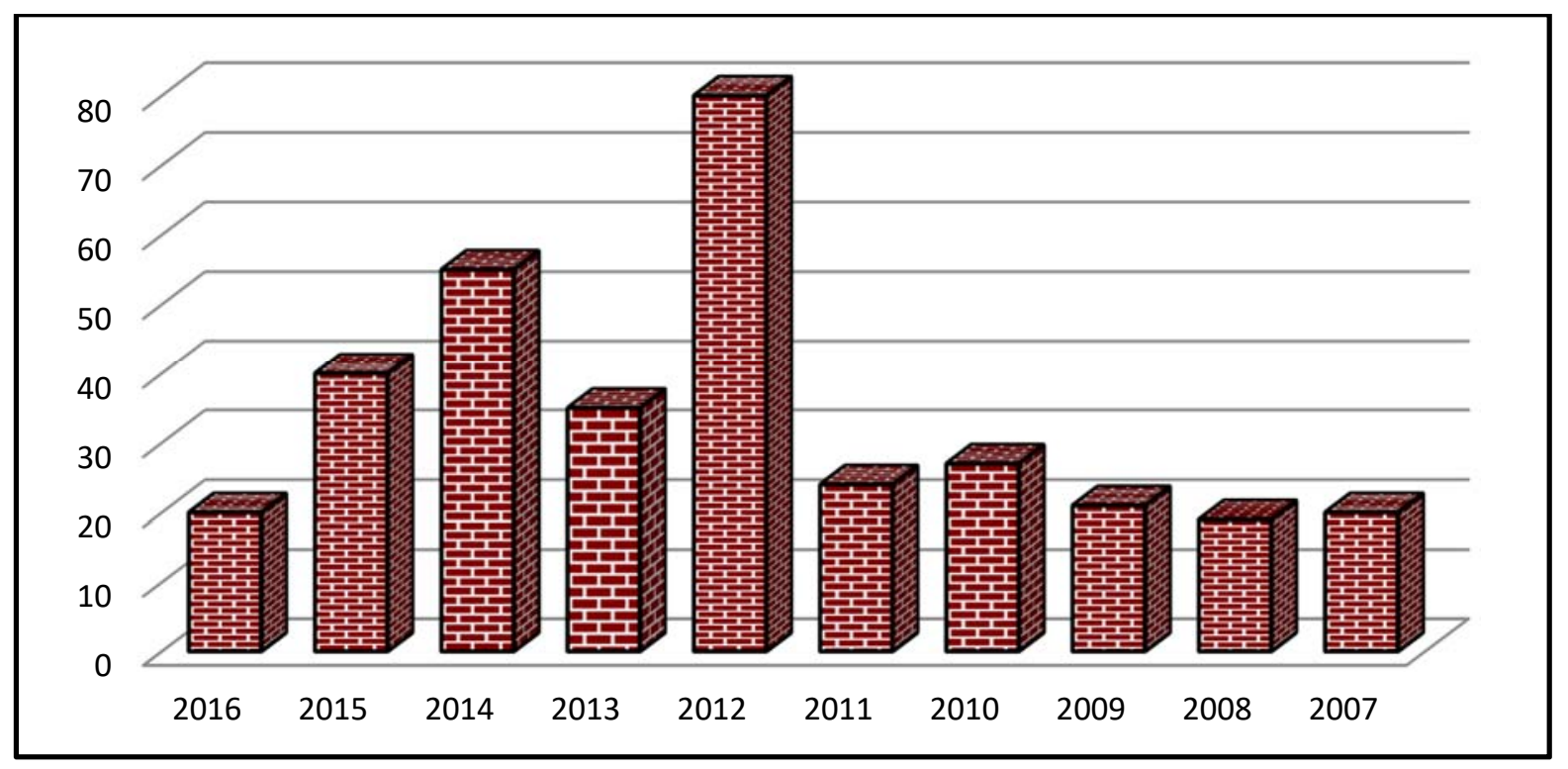

Figure 3: The year 2012 was the year with the highest number of applications.

\section{DISCUSSION}

Patents are one of the headstones of contemporary society today 4,11 . Patents are granted to the inventor for a certain period of time and prevent the reproduction, use or the trade of the product by others without permission ${ }^{5,12}$. The right also grants the owners permission to transfer their rights to third parties or allows them to use their rights for a certain period of time ${ }^{6}$.

The UM certificate brings along another kind of protection for inventions (Table 1). The 'utility model', dealt with in The Washington Treaty $7,13,22$ of 1911 for the first time, covers the industrially applicable invention, yet does not obligate for the 'inventive step - non-obviousness' criterion. Thus, protection of the inventions industrially applicable but without the inventive step is made possible. The UM certificate provides protection for 10 years.

Companies that applied to the TPTO for a trademark are classified according to the NACE codes. Section 3, Class 32.50 of the NACE codes covers medical instruments and supplies. In Turkey, 53 of the 20,976 applications in 2008 were in the field of Health Affairs ${ }^{8}$ and Social Services 
$(\% 0.25)$. However, there is no categorical or contextual explanation in this annual report. Still, the ratio can be considered very low in comparison to the European Patent Office data from 2011, where the highest number of patent applications $(24.8 \%)$ was for medical technologies ${ }^{9,14,15}$.

According to the TPTO data, the number of UM registries in $1998(\mathrm{n}=144)$ increased by 4.4 times and reached 632 in $2003^{8}$. In 2007, the number of UM applications was 3,017 in total $(2,973$ domestic, 44 foreign). When compared to the previous year, the rate of increase in UM applications was $22 \%$ in $2004,27 \%$ in $2005,29 \%$ in 2006 , and $23 \%$ in $2007^{8}$. As can be seen from above, there is a constant increase in the number of UM applications between 1998 and 2007 . However, these data do not contain the categorical details.

To the best of our knowledge, this is the first study that investigates the patents and UMs in the field of orthopedics and traumatology in Turkey. There was no significant and a_constant increase between 2007 and 2012, as it was between 1998 and $2007^{8}$, and the number of applications between 2012 and 2017 rose and fell irregularly. A review of the data showed that $49.3 \%$ of the applications were approved for registration. However, almost $30 \%$ of these registries had become invalid after registration due to unpaid legislative fees.

Spinal surgery took the lead in applications for patents and UMs by $35.5 \%$, followed by trauma surgery with $29.9 \%$. Among the subcategories, implants were the most patented devices with $60.7 \%$, followed by auxiliary tools with $18.2 \%$. The number of the patents and UMs for tumor surgery, pediatric orthopedics and microsurgery were the lowest.

The lack of similar research investigating the number of patents and UMs in the field of orthopedics and traumatology or other areas of medicine and thus our inability to make a comparison may be considered a limitation of our study. However, our research can be used as a reference in future studies investigating the patents and UMs in the field of orthopedics and traumatology. Further studies are required to monitor the progress regarding new patent and UMs to investigate productivity in the manufacturing of medical products.

\section{REFERENCES}

1. Karaahmet E. Patents, Trademarks and the Turkish Patent Institute as an information source. [Text in Turkish] Türk Kütüphaneciliği Dergisi 1995;9:386-97.
2. N. A. O. Boztosun, "Exploring the utility of utility models for fostering innovation". Journal of Intellectual Property Rights 15, p. 434 (2010) [http://nopr.niscair.res.in/handle/123456789/10 685].

3. Jabur WP, Santos MJP. Propriedade intelectual: criações industriais, segredos de negócio e concorrência desleal. Sao Paulo: Saraiva; 2007.

4. Ortan AN. The European Patent System: Vol. 1. European Patent Convention (The Munich Convention). [Text in Turkish] Ankara: Institute of Research on Bank and Trade Law, 1991.

5. Jabur WP, Santos MJP. Propriedade intelectual: criações industriais, segredos de negócio e concorrência desleal. Sao Paulo: Saraiva; 2007.

6. The Ministry of Science, Industry, and Technology. A Guide to Patent/Utility Model Applications. [Text in Turkish] Ankara: The Turkish Patent and Trademark Office, 2014.

7. Smith SW, Sfekas A. How much do physician entrepreneurs contribute to new medical devices? Med Care. 2013;51:461-7.

8. Ferreira FK, Song EH, Garcia EB, Ferreira LM. A new mindset in scientific method in the health field: design thinking. Clinics. 2015;70:770-2.

9. Elisiane Kiel Lee, Lydia Masako Ferreira, Elaine Kawano HoribeI. Patents on hospital medical and dental equipment (EMHO). Question and answer tool. Acta Cir Bras. 2019;34(1).

10. F. Narin and E. Noma, Is Technology \&coming Science?. Scientometrics (1985) 369-381.

11. Martin Meyer. Does science push technology? Patents citing scientific literatüre. Research Policy 292000 409-434.

12. Pavitt, K. Do patents reflect the useful research output of universities? SPRU Electronic Working Papers series. Paper No 6. Science Policy Research Unit, Brighton, also published in Research Evaluation.1998. 23, 105-111.

13. Ganguli, P, Blackman.Patent documents: a multiŽ. edge tool. World Patent Information.1995. 174 , 245-256.

14. Joaquín M. Azagra-CaroNicolas, CarayolPatrick Lierena. Patent Production at a European Research University: Exploratory Evidence at the Laboratory Level. The Journal of Technology Transfer March 2006, (31); 2;257-268. 
15. Keith Pavitt. Do patents reflect the useful research output of universities? Research Evaluation, 1998 ;(2) :105-111.

16. Petersmann EU. Human rights and the law of the World Trade Organization. JWT 2003;37:241-81.

17. Langinier $C$, Moschini GC. The Economics of Patents: An Overview. Working Paper 02-WP 293. Ames, Iowa: Center for Agricultural and Rural Development, Iowa State University, 2002.

18. Scherer FM. Industrial Market Structure and Economic Performance. $2^{\text {nd }}$ ed. Chicago: Rand McNally College Publishing Company, 1980.

19. Yalçıner UG. The Turkish Patent System and Its Management Today and Tomorrow. Paper presented at: International Symposium on Patent Systems and Patent Office Organizations. 1992 Oct 12-13; Ankara, Turkey.
20. Sectoral Classification of the Companies Applied to the Turkish Patent Institute for Trademark, Industrial Design and Patent [Internet]. [Website in Turkish]. Ankara: The Turkish Patent and Trademark Office. 2008 [cited 2017 Dec 01]. Available from: http://www.turkpatent.gov.tr/TURKPATENT/s tatistics/

21. Annual report 2011 - Statistics and trends [Internet]. Munich: European Patent Office. 2011 - [cited 2017 Dec 01]. Available from: https://www.epo.org/about-us/annual-reportsstatistics/annual-report/2011/statisticstrends/key-trends.html\#fields.

22. H. Kronz and H. Grevink, Patent statistics as indicators of technological and commercial trends in the member states of the European Communities (EEC). World Patent Informarion 1980. 